\title{
Representations of Labour Migration in Guatemalan and American Media
}

\author{
Harald Bauder
}

Ryerson University

\section{Genevieve Gilbert}

University of Ottawa

Please Cite:

Bauder, H., \& Gilbert, G. (2009). Representations of labour migration in Guatemalan and American media. ACME: An International Journal for Critical Geographies, 8(2), 278-303.

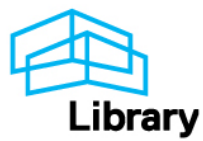




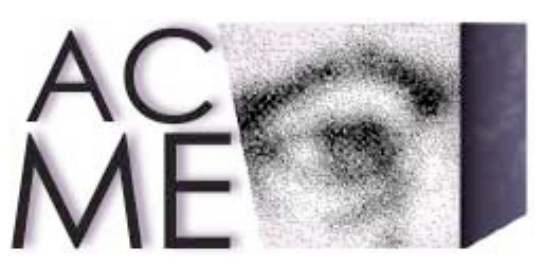

\title{
Representations of Labour Migration in Guatemalan and American Media
}

\author{
Harald Bauder ${ }^{1}$ \\ Department of Geography, Ryerson University, \\ Toronto, Ontario M5B 2K3, Canada \\ Email: hbauder@ryerson.ca

\section{Genevieve Gilbert} \\ Department of Geography, University of Ottawa, \\ Ottawa, Ontario K1N 6N5, Canada \\ Email: ggilb064@uottawa.ca
}

\begin{abstract}
International migration is an inseparable component of economic 'globalization'. It constitutes an important source of labour for industrialized economies, while developing countries increasingly depend on remittances sent by migrants. In this paper, we investigate media representations of the international migration process at both places of origin and destination. At the source, the Guatemalan media often acknowledges the influence of global economic relations on the migration process. Conversely, at the destination, the Los Angeles media often denies these relations and instead focuses on national and local scales of representation. In our interpretation, scale-particular representations work together to rationalize the departure of migrants from Guatemala and to legitimate their
\end{abstract}


subordination in the United States. These media representations are a contributing factor to an international system of labour regulation.

\section{Introduction}

Labour migration from Central America and Guatemala to the United States has reached unprecedented levels with the ascent of global neoliberalism in the 1980s and 1990s (Hamilton and Stoltz, 1991). Over the last decade, this migration flow continued. According to the U.S. Department of Homeland Security (2006) roughly 60,000 immigrants who previously resided in Central America officially came to the United States in 2000; almost 10,000 came from Guatemala. These numbers increased in 2005 to more than 74,000 from Central America, and almost 24,000 from Guatemala. These figures exclude large numbers of undocumented immigrants (Jefferys and Rytina, 2006). Los Angeles is the city with the world's largest number of Central American residents outside of Central America (Kohpahl, 1998).

In this paper we examine the media representations of the international migration process from two different vantage points: from the place of origin and the place of destination. Mass media plays a vital role in shaping public discourse and raising anxieties about social and economic change (Hall, 1977; Laclau, 1977). Media representations also constitute an integral element in the regulation of labour, in particular the labour of migrants and immigrants (Bauder, 2005, 2008). By examining the representation of immigration in the Los Angeles newsprint media and emigration in the Guatemalan media, we seek to unravel different meanings encoded by both media onto the same migration stream.

The results of a media content analysis reveal different and scale-particular representations of migrants and the migration process in the mainstream press in Los Angeles and Guatemala. While the Guatemalan media often acknowledges the influence of global economic processes on migration patterns, the Los Angeles media typically denies these processes and instead focuses attention on national and local causes and impacts of migration. While media discourses at both origin and destination may initially seem contradictory, their place- and scale-particular nature work together in legitimating existing migration practices and labour exploitation.

\section{Background}

\section{International Migration and the Global Economy}

Dependency Theory, developed by the Argentine economist Raúl Prebisch (1950), suggests that unequal political and economic relationships between nation states enable industrialized countries to systematically exploit the global periphery and appropriate surplus value (Lewellen, 1995; Frank, 1971). World System 
Theory makes a related argument that the division of labour in a global economic system enables core areas in the global north to economically dominate peripheral countries in the global south (e.g., Wallerstein, 1974, 1979). In recent decades, following the debt crisis of the 1980s, many peripheral economies have enacted neoliberal economic policies and strategies that further integrated them into the world economic system. In fact, some Latin American countries served as testing grounds for the neoliberal model (Peck, 2004). Powerful international institutions, including the International Monetary Fund and the World Bank, have assisted Guatemala and other Central American countries in implementing structural adjustment programs and helped create laissez-faire economic systems that endorse unfettered market forces and reduce state intervention (Gilbert, 2005). As an effect of economic restructuring, many countries of the global south have witnessed massive exploitation, poverty and growing inequality among their populations. In Guatemala, wealth has been extremely unevenly distributed (indicated by a GINI of 58.3). The poverty rate was 57 percent in $2002 ; 21.5$ percent of all Guatemalans lived in extreme poverty (Democratic Dialog, 2007).

In addition, inflowing foreign investment, agricultural production for export, the increasing modernization of production, and the feminization of the labour force uprooted many people from their 'traditional' economies and mobilized large segments of the population into the waged labour market. People previously involved in subsistence work witnessed the disruption of their traditional source of livelihood, the commoditization of their land and the 'Westernization' of their lifestyle (Sassen, 1989). Globalization and economic restructuring led to the migration of landless peasants and workers in search for the means of survival. International migration of Guatemalans to the United States must be understood in the context of intensive displacement. While some of these displaced workers migrated internally to the cities and other parts of the country, many others migrated to the United States (Hamilton and Stoltz, 1991).

Furthermore, the United States government's intervention in Guatemala's civil war exacerbated not only the dislocation of people but also triggered the migration flow of refugees to the United States (Schlesinger and Kinzer, 1999). Nora Hamilton and Chincilla Stoltz $(1991,106)$ observed almost two decades ago: "Overall, U.S. foreign policy appears to have been more effective in generating refugees than U.S. immigration and refugee policies have been in preventing their entry." The movement of capital, lifestyle and military interference from the United States to Guatemala has remained intimately connected to the movement of labour and refugees in the opposite direction. As a result of these processes, approximately one million Guatemalans lived abroad in 2004, mostly in the United States. Their remittances constituted more than 8 percent of Guatemala's Gross Domestic Product (Democratic Dialog, 2007). 
The ability to send remittances, however, does not mean that migrants are working in the upper segments of the labour market. The expansion of the lowwage employment sector has been a fundamental feature of neoliberalism - not only in the periphery but also in the industrialized countries in which migrants temporarily or permanently settle (Peck, 2001; Sassen, 1989). Before and after migration, workers from the global south who migrate to the north constitute a subordinate labour force, supporting global economic expansion and capital accumulation (ACME, 2003; Bauder, 2006b). Often migrants become "unfree" labour (Sharma, 1997; Cohen, 1987; Miles, 1987), bonded to jobs and employers through processes of discrimination, criminalization and legal subordination. They also become abstract labour, valued for their labour power but denied their humanity (Bauder, 2005; Mitchell, 1996).

In the urban context of Los Angeles, immigrants tend to "niche" in particular low-wage industries and occupations along origin and gender lines (Ellis et al., 2007). Guatemalans in Los Angeles tend to be particularly segmented into private household services in the case of women, and construction, machine- and transport-operation, and food-preparation occupation in the case of men (Wright and Ellis, 2000). The perceptions employers have of Latin American immigrants play an important role in the segmentation of these immigrants into the secondary segment of the labour market of Los Angeles (Waldinger and Lichter, 2003). Cultural representations thus link with material circumstances of Guatemalan migrants in the Los Angeles labour market. It is at this junction that the media contribute to the construction and reproduction of these perceptions and legitimate the subordination of Latino immigrant labour.

\section{Migration and Media in the United States and Guatemala}

Media communication and material circumstances are recursively related with each other. Decades ago, Raymond Williams $(1966,19)$ acknowledged the role of communication in the construction of material practices:

We have been wrong in taking communications as secondary. Many people seem to assume as a matter of course that there is, first, reality, and then, second, communications about it.... we need to say what many of us know from experience ... that the struggle to learn, to describe, to understand, to education is a central and necessary part of our humanity. This struggle is not begun, at secondary hand, after reality has occurred. It is, in itself, a major way in which reality is continually formed and changed.

From Williams we infer that messages and meanings encoded in media discourse help structure material circumstances and shape our taken-for-granted world. Forty-five years later, Roger Silverstone and Myria Georgiou $(2005,434)$ reaffirm in the context of media and the representation of migrants that " $[t]$ he media ... are 
absolutely crucial to the management of everyday life." They project collective imaginaries and narrations that provide "frameworks for inclusion, and by the same token, frameworks for exclusion" (Silverstone and Georgiou, 2005, 435; see also: Downing and Husband, 2005). Neither does the media independently articulate such frameworks, nor does it simply reproduce them. Rather, it incorporates and reformulates material practices of inclusion and exclusion (e.g., van Dijk, 1991, 1997).

Despite the connection between discourse and material practices, Jorge Bustamante (1983) observed already a quarter century ago that a considerable discrepancy exists between facts and public opinion in respect to immigration in the United States. For example, contrary to popular stereotypes, migrants in the United States tend to consume less in comparison to non-migrants, and their consumption patterns exert relatively little pressure on public resources (Sassen, 1989). Latino stereotypes continue to persist in the popular imagination of the United States (Berg, 2002). When elite discourses articulate negative stereotypes and anti-immigrant sentiments they often cite economic reasons (Burns and Gimpel, 2000). Media coverage tends to contribute to the perpetuation of stereotypes, the discrepancy between facts and public opinion, and the association of immigrants with economic costs (Henry and Tator, 2000; Mahtani, 2001). In addition, negative and exaggerated images of migrants project a sense of crisis and instil fear among the readership (Hier and Greenberg, 2002). The United States media has a long history of representing Latino immigrants in a light that facilitates and reproduces practices of exclusion (Flores, 2003). In a contemporary context, media coverage in the United States often blames migrants for increasing unemployment rates and draining social security coffers. Latin American women are often represented as hyper fertile and reported statistics of Latino families invoke images of welfare dependency, although empirical facts suggest otherwise (Chavez, 2004). Such media coverage undoubtedly shapes public opinion about Latino immigration in the United States.

Popular opinion in the United States is sceptical of international migration and immigrants. A survey by the polling organization Public Agenda revealed that almost eight out of ten respondents support stricter penalties on 'illegal" immigrants; more than half confirm that 'illegal' immigrants do not deserve legal protection; almost eight out of ten agree that the government should be able to hold non-citizens for up to seven days in detention without charge; and roughly two out of three believe that the United States admits too many immigrants (Los Angeles Times, 2005).

\footnotetext{
2 'Illegal' immigrant is a contentious term. We recognize that this label is a construct of social, cultural and legal processes of exclusion. We do not approve of the term, but reproduce it when the original source applied it. By placing the term in single quotes, we indicate its problematic nature.
} 
In Guatemala, popular opinion reflects high levels of anxiety about the country's inequitable income distribution and high poverty rates, and dissatisfaction with the slow transition towards becoming an equitable society after the end of the civil war. The Guatemalan CID Gallup polling agency reported that more than six out of ten Guatemalans believe that their country's economic development is problematic; three out of four are unhappy with the recent increase in the cost of living; most Guatemalans feel that their families' financial situation is deteriorating and will continue to worsen; and the majority attribute rising violence and crime to a lack of well-paying jobs (CID Gallup, 2005). Migration, however, is not seen as the source of economic hardship, but rather as a solution. According to the same poll, four out of five Guatemalans know someone who emigrated to the United States in search of work. James Tyner (1999) observes in the context of Filipino emigration that migrants are often depicted as "heroes and heroines", driven by patriotism and rewarded with economic success. The representation of emigrants as brave and heroic may be a common representation in sending countries and thus may also appear in Guatemalan press reporting.

Geographic research has long illustrated the connection between global, local and other scales (e.g., Dicken, 2003). The media, however, may deploy scale as a strategic mechanism in the construction of meanings associated with migration and economic processes. Research published over the last two decades illustrates how scale shapes and frames the geographical imagination (e.g., Delaney and Leitner, 1997; Herod, 1991; Howitt, 2002). Correspondingly, the media articulates imaginaries of economic processes and narratives of cultural inclusion and exclusion in a scale-particular manner. "Scale shifting" is a common strategy of representing and misrepresenting migrants and migration processes in order to support particular local and national interests (Bauder, 2005; Mitchell, 1996, 1998; Silvey, 2004). In relation to migration, feminist analyses and other critical scholarship have demonstrated the relevance of constructions of various scales, including the body, the household, the nation and international contexts (Silvey, 2004). For example, the scale of the body reveals important practices of the state towards migrants (Mountz, 2004); and the national scale enables the very construction of the category immigrant that facilitates social, political and economic exclusion (Bauder, 2006a). By "shifting" scale, different meanings and mechanisms of inclusion and exclusion can be associated with the migration of a population.

Sallie Marsden (2000) notes that scale situates capitalist production as well as social reproduction. The representation of migrants involves both processes of production and reproduction. For example, gendered media representations of seasonal agricultural migrants in Canada frame male migrant labour as an important production factor at the local scale. At the same time, the media situates the families and beneficiaries of remittances sent by these workers at the global scale. These gendered scale-particular representations legitimate on the one hand 
the exploitation of migrant workers and on the other hand justify the denial of permanent legal status and economic and social rights (Bauder, 2005).

Based on this literature, we developed a series of expectations that guided the empirical research process and our interpretation of the data. In particular, we expected that the representation of the same migration stream from Guatemala to the United States differs significantly in terms of scale and contents at the place of origin and destination. In addition, we anticipated that the Guatemalan media links migration to the global scale and puts the migration process in the context of economic globalization. In Los Angeles, we expected the media to frame migration at the local and national scales and to focus on the costs of immigration for the American public. Furthermore, we expected media reporting in Los Angeles to neglect the connection between international migration and global economic processes of labour displacement in the global south and thereby shift the perceived burden of accountability to the migrants themselves (Chang, 2000; Ochoa and Ochoa, 2005).

\section{Research Design}

In the analysis that follows, we examine strategic media representations of migration from Latin America to the United States at the origin and destination. In the United States, our investigation focuses on the city of Los Angeles. In this city, Guatemalans represent the third largest group of Central Americans. We did not narrow our geographical focus inside of Guatemala because this country is, with an estimated total population of only 14 million, relatively small.

In each area we selected two newspapers that are widely distributed and project a 'mainstream' collective imaginary of migrants and migration. Through the inclusion of two newspapers at each location, we intended to increase the sample size and diversify the sample. Since we focussed our study on centrist and 'mainstream' political opinion, we did not sample newspapers that cater to niche audiences, such as the Latino media in Los Angeles. ${ }^{3}$ The first newspaper we selected for Los Angeles is the Los Angeles Times. It had a circulation of 852,000 in 2006 and a readership that is mostly "white, non-Hispanic", relatively affluent, educated and politically liberal-oriented (Los Angeles Times, 2006). The second Los Angeles newspaper we chose is The Daily News. With a circulation of 157,000 in 2006 this paper is the second largest daily paper in the Los Angeles area.

\footnotetext{
${ }^{3}$ It is not our objective to compare the contents of different papers from the same location. Although a comparison between newspapers would be interesting and likely reveal fragmented processes of local identity construction, our study concentrates on the differences of media representations at the source and the destination. For reasons of methodological clarity, our analysis only distinguishes between newspapers from Los Angeles and Guatemala (although we do report below from which source a quote is taken).
} 
Politically, The Daily News is centre-right oriented and targets suburban readers (Burrelles Luce, 2007).

Compared to television and radio, the print media of Guatemala enjoys a reputation of being democratic and open (Dagron, 2007). The first paper we selected for our study is Prensa Libre, which has a weekday circulation of 116,000, represents the "interests of the progressive private sector" and "has been in the forefront of the struggle for freedom of expression" (Dagron, 2007). The second paper, La Hora, is a conservatively-oriented but independent afternoon newspaper and considered one of the major four daily papers of Guatemala (Barrios, 2002).

The Los Angeles newspapers were accessed through Gale Custom Data Base; Guatemalan newspapers were available through their websites. The sample frame covers the period between 1 January 1999 and 29 February 2005. The beginning of this period was defined by the electronic availability and searchability of material in all four selected newspapers. The final date included in the study was when the data was actually downloaded. Initially, we selected articles based on a search using the keywords "migrant(s)" and "migration" for the American newspapers and their Spanish translation for the Guatemalan newspapers. The articles identified by this keyword search were skimmed for their contents, and if they related to the topic of research they were included in the final sample. Skimming the articles also gave us an initial impression of the contents, which enabled us to experiment with additional keywords to identify articles that dealt with Guatemala-United States migration but that were not captured by the initial keyword search. Articles identified through the keywords "American dream," "economy," "Illegal(s)," "labour," "Latino(s)," and "public resources" were also included in the sample, if they contained material pertaining to our topic. The final sample consists of 65 American and 57 Guatemalan articles. In the analysis we focused on identifying narratives and themes within each location that appear in the articles contained in our sample. The quotes presented below are examples representing these narratives and themes. The quotes from Guatemalan newspapers were translated from Spanish into English.

Media discourse produces multiple meanings and interpretations of single issues and subjects (Crespi, 1997; Fairclough, 1992; Fowler, 1991). In fact, discourse may be the "most complex system of signification and, therefore, produces the maximum possibilities for different interpretations" (Burgess, 1990, 146). Therefore, when possible, we assessed the relative importance of narratives and representations through cross-referencing with poll statistics that substantiate or diminish the significance of particular viewpoints. A limitation we acknowledge is that the reliance on newspaper reporting restricts the extent to which the circumstances of individual migrants can be assessed.

We recognize that the media representations of migrants and migration in our study are embedded in different geographical and historical contexts. During 
the study period, the Guatemalan media was recovering from a repressive civil war in which media was controlled, manipulated and intimidated through violence (Schlesinger and Kinzer, 1999). While the Los Angeles media may enjoy greater formal freedom, it is likely regulated by powerful interests through discursive and cultural means (e.g., Fairclough, 1992, 2000). In addition, the samples were collected during a time when the United States media increasingly politicized immigration as an issue of national security. These differences may further contribute to distinct media perspectives of the migration processes in Guatemala and Los Angeles.

\section{Results}

\section{Guatemalan Perspectives of Migration}

The sense of economic crisis - a perception substantiated by the poll results presented earlier - is a reoccurring theme when Guatemalan newspapers report on international migration. The narrative articulated in this theme observes that migrants seek to improve their economic situation by going to the United States. Prensa Libre, for example, published poll statistics to validate the idea that the lack of economic opportunities in Guatemala is a main cause of migration: "We took a public opinion poll and of 235 Guatemalans, 162 would like to go to the United States. This would change if there were more opportunities [in Guatemala]" (Kepfer, 2004).

This narrative recognizes that the attempt to escape the Guatemalan economic crisis through migration persists, even as migrants are met with intolerance in the United States and the risk of deportation. Prensa Libre reported:

The economic crisis forces thousands of people to look for a better future than in their country, but much of their dreams are not realized. In the first six months of the year, 4,452 Guatemalans have been deported from the United States and Mexico ... and many return to try again. (Seijo and Palencia, 2004)

In the same vein, La Hora published an article that illustrates that deportation does not deter migrants in light of the lack of economic opportunities in Guatemala:

"I'm going north [again] even if they deport me." It took her [Izabal, a young migrant] twenty-five days to arrive and be admitted to the United States where she worked for fifteen days and was captured in a police raid. The others are trying for a second or third time [to migrate to the United States]. (Cáceres, 2005)

In the context of the narrative of economic crisis, we also encountered the acknowledgement of unequal power relations in Guatemalan society, and the 
recognition that neoliberal national policies have increased the rift between rich and poor Guatemalans, which "translates into new migration" (Garmendia, 2004). The Guatemalan press, however, do not represent the economic crisis as an entirely home grown problem. Rather than representing this crisis as the product of processes that occur at the national scale, the Guatemalan media tends to recognize the economic forces that operate at the global scale and that in turn result in poverty and unemployment in Guatemala, which are the trigger for international migration. For example, Presna Libre (2002) quoted Ademar Barilli, director of Casa del Migrante in the city of Tecún Umán in the Department of San Marcos:

The principle causes of migration from Central America are the economic crisis and the phenomena of globalization ... Barilli said that Guatemala and the rest of the countries in Central America have been beaten down because of this phenomenon which provokes migration. "Many campesinos have lost their land or have left it due to drought and they confront immense difficulties in order to survive, and globalization is very damaging to small businesses".

Apparently, the Guatemalan media recognizes the global embeddedness of the Guatemalan economy and in this context acknowledges the global scale.

In respect to migration, reporting in the Guatemalan media tends to connect emigration with the demand for labour in the United States. In some cases, the Guatemalan media demonstrate a keen awareness of the connection between migration and the structural dependence of industrialized economies on immigrant labour, as it has been proposed in the academic literature on the political economy of migration (e.g., Cohen, 1987; Bauder, 2006b). Prensa Libre, for example, writes: "The phenomenon of migration, far from diminishing, is increasing ... in a globalized and asymmetrical world in which the industrialized countries need a flow of people from the developing countries" (Garmendia, 2004).

Guatemalan press reporting tends to recognize that migrants are an attractive labour force to employers in the United States and other industrialized countries because of their high degree of vulnerability (Bauder, 2006b; Piore, 1979). The above cited article presents a quotation by immigration scholar Manuel Ángel Castillo on the simultaneous demand of labour and intolerance towards immigration in receiving countries:

The receiving countries have adopted hypocritical measures because they have two faces. On the one hand they speak of the necessity to hold back the arriving avalanche; but on the other hand they take advantage of cheap labour in order to maintain the growth of their economies. (Garmendia, 2004) 
The Guatemalan newspapers we surveyed expressed an awareness of migration-related economic practices that operate at the global scale by drawing attention to the international income gap and the lack of political will by the migrant receiving countries to narrow this gap. For example, when United States President George W. Bush proposed to create a temporary workers program for undocumented immigrants in January 2004, Prensa Libre published an editorial with the following response to Bush's proposal:

Underneath Bush's plan, millions of undocumented migrants will be left alone for a while - three years, maybe six - but thereafter, they will return to being undocumented. Whatever migration proposal, you would need to also include a program of investment that will level the salaries of the entire American Continent. With your proposal, you are dancing around the problem. You are neither permanently resolving the migration situation of eight million undocumented migrants, nor planning the basis for an ordered and secure flow of immigrants in the future to the United States. (Avalos, 2004)

Another topic, which the Guatemalan press covered extensively, relates to the issue of remittances. Most articles that covered this issue gave remittances a positive spin. In line with scholars who note the benefits of remittances (e.g., Orozco, 2002), Prensa Libre reported the following statistics:

Remittances sent by migrants constitute a second form of income foreign exchange. Remittances represent almost $10 \%$ of the Gross National Product of the country. The money of Guatemalans in the United States sent to their families in Guatemala sustains 722469 families: more than 4 million people. (Kepfer, 2004)

The positive economic effect of remittances has become deeply ingrained in Guatemalan media reporting. It sends a powerful message to the readership that global economic inequalities can be met effectively with migration.

Nevertheless, press reporting was not naïve about the economic processes at the global scale that constitute the root causes of migration and create the need for remittances in the first place. The following quote from Prensa Libre puts remittances into the context of the asymmetrical economic relationship between the United States and Guatemala: "The trust and happiness with the continued growth in family remittances, is the same as accepting that our country is condemned to misery and underdevelopment" (García, 2005). The awareness of the link between global economic structures, international migration and remittances exemplify the recognition of the global scale in the Guatemalan sample of newspaper articles. 
Some articles juxtapose the value of remittances with the negative personal experience of migration. For example, Prensa Libre presents the following quote from Maricela Garcia, the president of the Coalición de Inmigrantes Guatemaltecos (Conguate), an organization that defends the rights and promotes the integration of Guatemalans in the United States:

Immigration is painful: it entails leaving everything one knows and loves, putting your life at risk in order to arrive in a county where you are invisible because you don't have documents. This is a violation of human rights and it doesn't permit immigrants to live with dignity. In Guatemala, all that is seen of immigrants is the remittances that they send. (Rodríguez, 2004a)

By acknowledging the sacrifices made by the migrants who send remittances, such newspaper reports put these remittances in a critical perspective.

Another important feature of Guatemalan print media coverage thus relates to the dangers and hardship endured by the migrants. Contrary to our expectation to encounter images of heroic migrants and emigrant success stories, we found reports of suffering, humiliation and failure. For example, Prensa Libre reported about a divided family: "Juan is scared for his wife. Now he only waits for them to send her back to Guatemala. But why? 'So we can try to leave again, since I have to support my five children"' (Seijo and Palencia, 2004).

Both Guatemalan newspapers we surveyed highlight this critical perspective of migration. For example, Prensa Libre reports about the unfavourable conditions which migrants face in the United States:

The limitations and hardships of more than a million immigrants who live in the United States range from the lack of health services and education to legal problems, which put them at risk of being deported by the American authorities. (Rodríguez, 2004b)

Similarly, a reporter for Prensa Libre notes the stereotypes which Guatemalan migrants encounter in the United States:

There is a mistaken perception ... They [immigrants] are the scapegoat for everything: if there is a crime, it is the immigrant; if there is a problem, it is the immigrant. The perception is that we Latinos are illiterate, that we come to use up public services and that we represent a threat because we bring our language and our culture. (Rodríguez, 2004a)

Many articles present examples of specific individuals to convey the personal hardship endured by migration. An article in Prensa Libre informs its 
readers how Guatemalans are treated as criminals in the United States and implies that migrants are humiliated to a degree that they are embarrassed to use their name: "We are mixed in with prisoners. We will be judged like delinquents; shackled by our feet, hands and waist. 'It is humiliating,' said Ludwid Marroquin, the only migrant to give his name" (Seijo and Palencia, 2004). This image of the humiliated migrant contradicts the idea of a heroic fortune seeker who succeeds abroad and returns victoriously. Newspaper stories about the humiliation of migrants are sometimes supplemented with reports of estrangement and nonbelonging. A migrant living in the United States brings this perspective of estrangement and non-belonging to the point when she reported in Prensa Libre: "At the bottom of it, we are outsiders in the country" (Munaíz, 2004). By deploying the scale of the body (that is shackled), the individual (who has a name) and the person (who is an outsider), Guatemalan media reporting personalizes the migration process and its effects.

Several newspapers further shine a critical light on migration by reporting on the dangers migrants encounter en route to the United States. An example published in La Hora links the dangers of this journey again back to the economic crisis, generated by international dependencies and economic domination:

In some parts of the journey, undocumented men, women and adolescents confront another danger: when the train is traveling at a slow speed or stops, delinquent groups called maras appear. They are also products of poverty, political instability, and socioeconomic crisis that Central America suffers, but they are organized in gangs and their objective is violence. (Cáceres, 2005)

The above evidence illustrates that newspaper reporting in Guatemala links various aspects of migration to processes and practices that relate to international and global scales as well as the scale of the individual and the body.

\section{Los Angeles Perspectives of Migration}

In contrast to the Guatemalan media, the Los Angeles media typically presents the issue of migration at local and national scales, and neglects economic relationships that exist at international and global scales. For example, a cover story in the Los Angeles Times associates the causes of migration with national border security, and portrays the economic effect as a state-wide phenomenon:

Because the nation can't control its border, the number of illegal immigrants grows by an estimated half-million each year. They come because we invite them with lax law enforcement and menial jobs. Their presence makes our own poor more destitute, creating a Third World chaos in the California economy that we are only beginning to understand. (Dickey, 2003) 
In this quote, the presumed causes and effects of migration are national and local. International economic relationships seem irrelevant to the logic of the argument.

Other debates of migration-related issues further illustrate the print media's fixation on the national scale: while the Guatemalan press related President Bush's proposed temporary workers program to international income inequalities, the Los Angeles media discussed this proposal from a perspective situated at the national scale. The Los Angeles Times published a quote by a law professor which argues that the proposal fails at the national scale of immigration policy: "It's camouflaged amnesty. No one wants to use the word 'amnesty' because the American people recognize it for what it is - admitting defeat of our immigration system" (Dickey, 2003). Again, this quote associates the cause of unwanted immigration with the national immigration system and neglects international and global perspectives of migration. Another illustration of the focus of media debate at the national scale is the striking absence of reporting on remittances in both sampled Los Angeles newspapers. This absence indicates the relative insignificance these newspapers associate with the global scale and the international embeddedness of migration. ${ }^{4}$

A reoccurring narrative in the Los Angeles newspapers is that migrants from Latin America exploit the social services available in the United States and pass on the costs to United States taxpayers. Newspapers often quote statistics to convey the costs of migration to their readers. For example, the Daily News (2000) states: "The cost [of illegal immigrants] to the taxpayers is $\$ 83$ million a year". The article, however, fails to clarify whether the figure refers to California, the United States or any other political entity. Apparently, the large number of $\$ 83$ million suffices to convey the magnitude of the threat posed by undocumented immigration. The issue of scale in this context does not even seem relevant to newspaper reporting. In another example, the Daily News (2000) writes: "What is known is how the tax drain is changing society ... someone else pays". Compared to the Guatemalan newspapers, which acknowledge global relations of dependency and domination, the Los Angeles media turn the tables and point the finger at the migrants as the source of economic hardship.

A counter narrative contained in our sample of newspaper articles recognizes that immigrants are a structurally necessary labour force ${ }^{5}$ for the economies of the United States and California. Deploying the national scale, many articles reflect the idea that the United States has become dependent on

\footnotetext{
${ }^{4}$ We found this absence very surprising since, in other media contexts, the flow of money earned by migrant workers from industrial countries to poor families in Latin America is constructed as something positive and a form of foreign aid (Bauder, 2008).
}

${ }^{5}$ The notion of migration as a "structural necessity" has been developed by Robin Cohen $(1987,135)$. 
undocumented labourers who often perform jobs that citizens do not want. The Los Angeles Times writes: "Undocumented immigrants have become an essential, perhaps inextricable, part of the U.S. labour force" (Vieth, 2004). The growth of the American economy in tandem with the growth of immigration is clearly illustrated in the following excerpt from the same newspaper:

Around 5 a.m. each day, thousands of people line up at these agencies looking for minimum-wage jobs ... Many are recent immigrants. Many are homeless. They work on assembly lines, in construction, landscaping or hotels. ... Experts say the temp industry took off after the 1982 recession spurred American companies to downsize, creating demand for a cheaper, more flexible workforce. As the economy rebounded, companies began to depend on day laborers. (Grossman, 2000)

Some newspaper articles present these conflicting views (i.e., the perceived cost immigration produces and the benefit it creates for the United States economy) simultaneously. The Los Angeles Times states: "Even cities big enough not to fear for their survival rely on Latino workers to keep their economies humming" (Simon, 2002). Despite the juxtaposition of costs and benefits of immigration, an imbalance exists in news media reporting in that the discussion remains fixed at the local and national scales, rarely incorporating processes at the international or global scales.

In an apparent contradiction with the image of migrants as essential labour for local and national economies, the value of immigration is diminished through the portrayal of immigrants as social problems and criminals. In our sample of articles, high birth rates among Latina women are often blamed for infrastructure degradation and an increase in poverty. For example, The Daily News reports that a high level of immigration

... undermines the economy, overtaxes schools and other services, and creates a permanent underclass of uneducated and unskilled poor, a nonpartisan think tank said in a report on Tuesday. ... The report by the Center for Immigration Studies [CIS]6, a Washingtonbased research organization focusing on immigration, cited Southern California as the epicenter of social and economic ills. (Hillburg, 2001)

\footnotetext{
${ }^{6}$ The Center for Immigration Studies (2007, no page) claims to be a "pro-immigrant, low-immigration" advocacy group; the Internation Socialist Review (2006) asserts that this center is associated with the racist Right.
} 
The newspapers often use quotes by prominent politicians to convey the socially problematic nature of immigration. In the context of high fertility rates among Latina immigrants, the Los Angeles Times quotes John Vasconcelleos, a Democratic state senator from San Jose: "The state is truly in dire straits. I'm not a pessimist and I'm not a doomsayer, but I've never been so frightened by the state in all my 37 years of serving the Legislature" (Green, 2004). Press reporting of this sort creates an atmosphere of anxiety and fundamental crisis associated with the growth of the immigrant population.

We found several articles that suggest that Latin American women cross the American border in order to give birth to their babies in the United States and that child birth is a deliberate strategy among immigrants to abuse the welfare system. Although researchers have demonstrated that immigrants use relatively few social resources (e.g., Chang, 2000), media reports continue to promote the idea that immigration drains social security coffers, the medical system and other social resources. Immigrants are represented as undeserving beneficiaries of public spending.

The simultaneous references in the media to the positive economic effect of cheap immigrant labour and the construction of Latino immigrants as social burden are not necessarily a contradiction. The following statement in The Daily News blatantly puts the two ideas together in the same paragraph: "Barring these [education] and other benefits, such as health care, would go a long way to solving the immigration problem. American demand for labour is a significant force promoting transnational migration to the United States" (Carney and Hiestand, 1999). This combination of the two seemingly opposing narratives produces the dual effect of objectifying and subordinating immigrant labour. The representation of migrants as essential labour but as unwanted members in the community is a discursive strategy to construct migrants as abstract labour that can be denied humanity and claims to social and economic rights (Bauder, 2005, 2008). The two narratives thus justify the use of Latino immigrants as labour in the United States economy and simultaneously strip them of any social and political agency that would compromise this use.

The construction of immigrants as undeserving of social and economic rights culminates in their criminalization, which is common in the two Los Angeles newspapers. The Los Angeles Times featured a speech at Arizona State University by Kathy McKee of the organization Protect Arizona NOW:

[She] told the mostly student audience that many illegal immigrants are not coming to Arizona to work. "Some come for crime. Some come for welfare. Some come for a good, cheap education. We are trying to take away the incentives," said McKee, who used the analogy of taking away cheese from a mouse. 
"Come on. Wake up," said Cindy Billings during her turn at the microphone. "We have to do something. 'Illegal' means it's against the law, and we need to enforce it. It's not racist." (Marosi, 2004)

According to this argument, immigrants are not only moral delinquents who abuse the welfare and educational systems, but they are also legal criminals who should be subjected to rigorous law enforcement practices. The narrative of the 'illegal' migrant draws broad support from the United States public, as reflected in the poll results we presented above. The use of the category 'illegal' demonstrates again that the issue of migration is situated at the national scale, at which belonging and non-belonging are expressed in reference to the legal structure of the nation-state (Bauder, 2006a, forthcoming).

In the context of this narrative of the 'illegal' immigrant, the link between discursive processes and material circumstances is established through reporting that makes recommendations to law-makers and state agencies. For example, the Los Angeles Times reports:

A controversial new study by a Washington group favoring reduced levels of immigration draws a grim picture of the economic and social consequences of large-scale immigration to the United States ... the continuing influx of poor settlers from Mexico provides marginal economic benefits while burdening public services and schools and creating generations of poverty. ... The study's recommendations include more guards and barriers along the U.S Mexico border and deep cuts in legal immigration. (McDonnell, 2001)

Although this article fails to name the Washington group which published this study, ${ }^{7}$ newspaper reporters and editors obviously select information that presents the viewpoint to the reader that immigration is a national-scale 'problem' and therefore requires a national-scale 'solution'. This scale-particular representation of migration legitmates the creation of a vulnerable migrant labour force in the United States, while not challenging international economic relations of dependence and domination.

\section{Conclusion}

The same stream of migration - from Latin America to Los Angeles - is represented very differently by the mainstream press at its origin and destination.

\footnotetext{
${ }^{7}$ The media apparently presents these groups as respectable organizations that enjoy broad support. However, many groups such as CIS, FAIR, and Numbers USA have the same staff, the same funding sources and the same agenda. All three of these groups were founded by the same man, John Tanton (Chou, 2003, 4).
} 
The dominant narratives in the Guatemalan newspapers draw clear links between Guatemala's situation in the global economy, neoliberal practices and policies, and the resulting flows of migrants. The Guatemalan media further tends to portray migration as humiliating and extremely dangerous with high personal costs. In addition, it often presents an image of the United States as a place of injustice and hardship for migrants. The Guatemalan media tends to recognize that migrants are rendered non-humans and abstract labour in the United States.

Contrary to our initial expectations, we did not encounter the image of heroic migrants who successfully venture out into the world and create opportunities for themselves and their families (Tyner, 1999). What we found instead is a narrative that acknowledges the humiliation that migrants experience in the United States. Even in the context of remittances, our analysis did not uncover images of brave migrants who endure suffering for their families, but rather a factual recognition that global economic processes create the circumstances that trigger migration as a matter of necessity. The simultaneous acknowledgement of hardship faced by migrants and the dire economic realities in Guatemala projects a sense of imprisonment that represents Guatemalans as having few other options for survival but migration. While state-managed emigration discourse in the Philippines follows the script of fortune seeking and upward mobility, the Guatemalan media discourse focuses on the themes of desperation and economic survival. Unfortunately, it is beyond the scope of this study to further explore the differences between the representations of emigration in Guatemala and the Philippines.

Unlike the Guatemalan media, which stresses that migrants are human beings and deserve basic social and economic rights, the Los Angeles newsprint media tends to depict immigration as an us-against-them issue, whereby Latin Americans invade and exploit the United States and its tax payers. It tends to paint an image of immigrants as being disconnected from society in the United States and not belonging to the local community. In addition, media reporting often criminalizes Latino immigrants as 'illegal'. This narrative of non-belonging and 'illegality' denies migrants their agency and their social and political legitimacy. Rarely does the Los Angeles media question the political and legal processes of exclusion that produce the category of 'illegal' in the first place. The representation of Latino immigrants as undeserving and criminal and the denial of their humanity go hand-in-hand with their representation as abstract labour and as a vital production factor for the local and national economies. These representations are gendered. In our sample, immigrant women, in particular, were represented as undeserving and a burden on the social infrastructure.

Geographical scale is a discursive strategy deployed in the representations of migrants by Guatemalan and Los Angeles media. In both places, the nature of newspaper reporting on migration is related to particular productions of scale. The 
Guatemalan media tends to present migration to the United States as an international phenomenon that relates to global economic processes and dynamics. This perspective of news reporting demonstrates a geopolitical awareness of the global embeddedness and economic dependence of Guatemala. In light of this country's political and civil struggles over the last decades and its history of external political and economic interference, it is no surprise to encounter this perspective in an increasingly confident and independent press. At the same time, the Guatemalan media occasionally presents immigrants at the scale of the individual and the body, and thereby personalizes migration experiences.

The Los Angeles media, on the other hand, tends to shift its reporting and interpretation of migration to the national and local scales. At these scales, media reporting emphasizes the threat of immigration to national and local social order, while acknowledging the economic benefits of immigrant labour. In our interpretation, this perspective parallels the interests of local and national capital, which benefits from the availability of immigrant labour that is rendered vulnerable through social, cultural and legal practices of exclusion (Bauder, 2006b). At the same time, the focus on national and local scales pulls attention away from the larger economic and structural forces that drive transnational migration, ignores a global perspective that would offer a more comprehensive treatment of the costs and benefits of migration, and denies migrants their humanity. If this logic that migration practices and economic processes are confined to the national scale is embraced by the political actors and the population as a whole, it tends to discourage political and compassionate efforts on the side of immigrant supporters, labour unions and other organizations in the United States to relieve personal hardship and organize transnationally. The recent immigrant protests in Chicago, Los Angeles, Washington D.C. and other cities have illustrated how the representation of immigrants and immigration in the United States is tied to nationalism and the national scale (Bauder, 2006a).

Media discourse has concrete material effects. Media representations are not passive reflections of popular opinion but they can actively shape politics, social practices and the economic circumstances that affect migrants. It is beyond the scope and the research design of this paper to precisely trace how this link between material and discursive practices operates. Nevertheless, we can interpret our findings on media discourse in light of the existing material on migration and labour practices. In Los Angeles, the treatment of Latin American migrants by employers, public agencies and non-migrant citizens (e.g., Ellis et al., 2007; Ochoa and Ochoa, 2005; Waldinger and Lichter, 2003) corresponds to the representations of these migrants offered in the media as non-belonging, subordinate and undeserving. These representations may serve to legitimate existing policies and practices that render immigrant workers subordinate. In Guatemala, media discourse tends to project a sense of economic crisis that may encourage workers to migrate to the United States as an economic survival strategy. The 
acknowledgement of the value of remittances may further justify the decision by many Guatemalans to embark on the journey north. In addition, the acknowledgement of the dangers of the journey, the abuse and humiliation in the United States, and the possibility of deportation rationalize the lack of quick success and the improbability of a heroic return as a wealthy person. The contradictory media representations of migration at both source and destination legitimate material labour and migration practices that are characterized by the mass departure of Guatemalans and their employment as subordinate and vulnerable labour in Los Angeles and the United States.

\section{Acknowledgements}

We thank the Centro de Investigaciones Regionales de Mesoamérica (CIRMA) for helping facilitate this research. Michael Samers, Mary Gilmartin and three additional anonymous reviewers provided very useful feedback.

\section{References}

ACME. 2003. Themed issue: Borders and immigration. Vol. 2, No. 2, http://www.acme-journal.org/Volume2-2.htm .

Avalos, Jorge. 2004. Gracias Bush, pero no es suficiente: Una propuesta poco realista para aplaudirla. Prensa Libre, 18 January, no page.

Barrios, Gabriela, 2002. Un mercado para todos los gustos. Prensa Libre (website), http://www.prensalibre.com (accessed 28 December 2007).

Bauder, Harald. Forthcoming. "Emotional attachment ... to what? A reply to Stanley Renshon." Migrations and Identities 1(2), in press.

Bauder, Harald. 2008. Foreign farm workers in Ontario (Canada): Exclusionary discourse in the newsprint media. Journal of Peasant Studies 35(1), 100-18.

Bauder, Harald. 2006a. And the flag waved on: Immigrants protest, geographers meet in Chicago. Environment and Planning A 38(6), 1001-04.

Bauder, Harald. 2006b. Labor Movement: How Migration Regulates Labor Markets. New York: Oxford University Press.

Bauder, Harald. 2005. Landscape and scale in media representations: The construction of offshore farm labour in Ontario, Canada. Cultural Geographies 12, 41-58.

Berg, Charles Ramírez. 2002. Latino Images in Film: Stereotypes, Subversion, Resistance. Austin: University of Texas Press. 
Burns, Peter and James G. Gimpel. 2000. Economic insecurity, prejudicial stereotypes, and public opinion on immigration policy. Political Science Quarterly 115(2), 201-25.

Burrelles Luce. 2007. Top 100 daily newspapers in the US by circulation. http://www.burrellesluce.com/top100/2006 Top 100List.pdf (accessed 28 December 2007).

Burgess, Jacquelin. 1990. The production and consumption of environmental meanings in the mass media: A research agenda for the 1990s. Transactions of the Institute of British Geographers 15,139-61.

Bustamante, Jorge A. 1983. The Mexicans are coming: From ideology to labor relations. International Migration Review 17, 323-41 .

Cáceres, Carlos. 2005. La migración indocumentada y el tren de la muerte. La Hora, 5 January, no page.

Carney, Steve and Jesse Hiestand. 1999. Costs, benefits associated with illegal immigrants. Daily News (Los Angeles, CA), 18 April, N3.

Center for Immigration Studies. 2007. About the Center for Immigration Studies. http://www.cis.org/aboutcis.html (accessed 28 December 2007).

Chang, Grace. 2000. Disposable Domestics: Immigrant Women Workers in the Global Economy. Cambridge, MA: South End Press.

Chavez, Leo R. 2004. A glass half empty: Latina reproduction and public discourse Human Organization 63(2), 173-88.

Chou, Eunice Hyunhye. 2003. Who's behind the attack on immigrants? Exposing the anti-immigrant right. Network News: National Network for Immigrant and Refugee Rights (Spring-Summer), 4.

CID Gallup. 2005. Previous Studies. http://www.cidgallup.com/en/opinion.shtml (accessed August 2005)

Cohen, Robin. 1987. The New Helots: Migrants in the International Division of Labour. Aldershot, UK: Avebury.

Crespi, Irving. 1997. The Public Opinion Process: How the People Speak. London: Lawrence Erlbaum Associates Publishers.

Dagron, Alfonso Gumucio. 2007. Media in Guatemala: From war to censorship. MediaChannel. http://www.mediachannel.org/views/oped/guatemala.shtml (accessed 28 December 2007). 
Daily News. 2000. Briefly more inmates are illegal immigrants (Los Angeles, CA), 7 December, N8.

Delaney, David and Helga Leiter. 1997. The political construction of scale. Political Geography 16(2), 93-7.

Democratic Dialog. 2007. Guatemala. United Nations Development Programme. http://www.democraticdialoguenetwork.org (accessed 28 December 2007).

Dicken, Peter. 2003. Global Shift: Reshaping the Global Economic Map in the $21^{\text {st }}$ Century. $4^{\text {th }}$ Edition. New York: Guilford.

Dickey, Fred. 2003. Undermining American workers: Record numbers of illegal immigrants are pulling wages down for the poor and pushing taxes higher. Los Angeles Times, 20 July, Part 1, 12.

Downing, John and Charles Husband. 2005. Representing Race: Racisms, Ethnicities and Media. London: Sage.

Ellis, Mark, Richard Wright, and Virginia Parks. 2007. Geography and the immigrant division of labor. Economic Geography 83(3), 255-81.

Fairlcough, Norman. 1992. Discourse and Social Change. Cambridge, UK: Polity Press.

Fairclough, Norman. 2000. Language and neoliberalism. Discourse and Society 11(2), 147-48.

Flores, Lisa A. 2003. Constructing rhetorical borders: Peons, illegal aliens, and competing narratives of immigration. Critical Studies in Media Communication 20(4), 362-87.

Fowler, Robert. 1991. Language in the News: Discourse and Ideology in the Press. New York: Routledge

Frank, Andre Gunder. 1971. Capitalism and Underdevelopment in Latin America. New York: Monthly Review Press.

García, César A. 2005. Hablando Claro: Esperanzados en la pobreza. Prensa Libre, 12 April, no page.

Garmendia, Maite. 2004. Manuel Angel Castillo: Migrantes son personas. Prensa Libre 9 May, no page. 
Gilbert, Alan G. 2005. The economy: growth diversification, and globalization. In, Brian W. Blouet \& Olwyn M. Blouet (eds.), Latin America and the Caribbean. Haboka: John Wilely \& Sons.

Green, Lee. 2004. A human wave is breaking over California. Los Angeles Times, 25 January 25, Part 1, 12.

Grossman, Kate N. 2000. Day laborers organizing to fight temp agency employment abuses. Los Angeles Times, 16 July, A14.

Hall, Stuart. 1977. Culture, the media and the ideological effect. In, James Curran (ed.), Mass Communication Society. London: Open University Press, pp. 315-48.

Hamilton, Nora and Chinchilla Stoltz. 1991. Central American migration: A framework for analysis. Latin American Research Review 26(1), 75-110.

Henry, Frances and Carol Tator. 2000. Racist Discourse In Canada's English Print Media. Toronto: Canadian Race Relations Foundation. http://www.crr.ca (accessed 28 December, 2007)

Herod, Andrew. 1991. The production of scale in United States labour relations. Area 23(1), 82-8.

Hier, Sean P. and Joshua L. Greenberg. 2002. Constructing a discursive crisis: Risk, problematization and illegal Chinese in Canada. Ethnic and Racial Studies 25, 490-513.

Hillburg, Bill. 2001. Report: Mexican immigrants a drain on region's resources. Daily News (Los Angeles, CA), 13 July, N1.

Howitt, Richard. 2002. Scale and the other: Levinas and geography. Geoforum 33, 299-313.

Internation Socialist Review (2006) Special feature: The politics and economics of immigration. Vol. 50 (November-December).

Jefferys, Kelly and Nancy Rytina. 2006. U.S. Legal Permanent Residents: 2005. Homeland Security.

http://www.uscis.gov/graphics/shared/statistics/publications/USLegalPermEs t 5.pdf (accessed 20 June 2006)

Kepfer, Crista. 2004. Migrantes demandan participación cívica: Insisten en derecho a voto; Govierno asume compromisos. Prensa Libre, 17 June, no page. 
Kohpahl, Gabriela. 1998. Voices of Guatemalan Women in Los Angeles:

Understanding Their Immigration. New York: Garland Publishing.

Laclau, Ernesto. 1977. Policy and Ideology in Marxist Theory. London: New Left Books.

Lewellen, Ted. 1995. Dependency and Development: An Introduction to the Third World. Westport CT: Berginand Garley.

Los Angeles Times. 2005. Public Agenda, http://publicagenda.org/issues/majprop.cfm?issues type=immigration (accessed March 2006).

Los Angeles Times. 2006. Circulation \& Readership. http://www.latimes.com/extras/ads/circ 05.html (accessed 28 December 2007)

Mahtani, Minelle. 2001. Representing minorities: Canadian media and minority identities. Canadian Ethnic Studies 33(3), 99-133.

Marsden, Sallie A. 2000. The social construction of scale. Progress in Human Geography 24(2), 219-42.

Marosi, Richard. 2004. Decade later, Prop. 187 has an echo in Arizona. Los Angeles Times, 23 October, A1.

Massey, Douglas. 1995. The new immigration and ethnicity in the United States Population and Development Review 21, 631-52.

McDonnell, Patrick. 2001. Dim view of Mexico migration. Los Angeles Times, 13 July, 1 .

Miles, Robert. 1987. Capitalism and Unfree Labour: Anomaly or Necessity. London: Tavistock Publications.

Mitchell, Don. 1998. Scales of justice: Localist ideology, large-scale production, and agricultural labor's geography of resistance in 1930s California. In, Andrew Herod (ed.), Organizing the Landscape: Geographical Perspectives on Labor Unionism. Minneapolis: University of Minnesota Press, pp. 159-94.

Mitchell, Don. 1996. The Lie of the Land: Migrant Workers and the California Landscape. Minneapolis: University of Minnesota Press.

Mountz, Alison. 2004. Embodying the nation-state: Canada's response to human smuggling. Political Geography 23(3), 323-45. 
Munaíz, Claudia. 2004. Las esquinas de la esperanza: Migrantes esperan oportunidad en calles de Los Ángeles. Prensa Libre, 2 July, no page.

Ochoa, Enrique C. and Gilda L. Ochoa (eds.) 2005. Latino Los Angeles:

Transformations, Communities, and Activism. Tucson: University of Arizona Press.

Orozco, Manuel. 2002. Globalization and migration the impact of family remittances in Latin America. Latin American Politics and Society 44, 41-66.

Peck, Jamie. 2004. Geography and public policy: Constructions of neoliberalism. Progress in Human Geography 28, 392-405.

Peck, Jamie. 2001. Workfare States. New York: Guilford Press.

Prebisch, Raúl. 1950. The Economic Development of Latin America and Its Principal Problems. Lake Success, NY: United Nations.

Presna Libre. 2002. Crisis económica causante de migración en Centroamérica, 6 March, no page.

Rodríguez, Luisa. 2004a. Marcela Garcia: El reto es dignificar a los inmigrantes. Prensa Libre 20 June, no page.

Rodríguez, Luisa. 2004b. Los migrantes pedirán apoyo: Lideres se reunirán con Oscar Berger en Washington, D.C. Prensa Libre. April 25, no page.

Sassen, Saskia. 1989. The Mobility of Labor and Capital: A Study in International Investment and Labor Flow. New York: Cambridge University Press.

Schlesinger, Stephen and Stephen Kinzer. 1999. Bitter Fruit: The Story of the American Coup in Guatemala. Cambridge, MA: Harvard University Press.

Seijo, Lorena and Gema Palencia. 2004. Migración: Seis mil 742 deportados cada mes, Prensa Libre 30 August, no page.

Sharma, Nandita. 1997. Birds of prey and birds of passage: The movement of capital and the migration of labour. LABOUR, Capital and Society 30, 8-38.

Silverstone, Roger and Myria Georgiou. 2005. Editorial introduction: Media and minorities in multicultural Europe. Journal of Ethnic and Migration Studies 31(3), 433-41.

Silvey, Rachel. 2004. Power, difference and mobility: Feminist advances in migration studies. Progress in Human Geography 28(4), 490-506. 
Simon, Stephanie. 2002. Latinos take root in Midwest. Los Angeles Times, 24 October, Part A, 1.

Tyner, James A. 1999. The web-based recruitment of female foreign domestic workers in Asia. Singapore Journal of Tropical Geography 20, 193-209.

U.S. Department of Homeland Security. 2006. Yearbook of Immigration Statistics, Table 2 - Persons obtaining legal permanent resident status by region and selected country of last residence: Fiscal years 1820 to 2006. http://www.dhs.gov/ximgtn/statistics/publications/yearbook.shtm (accessed 28 December, 2007).

van Dijk, Tuen A. 1991. Racism and the Press. London: Routledge.

van Dijk, Tuen A. (Ed). 1997. Discourse Studies: A Multidisciplinary Introduction. London: Sage.

Vieth, Warren. 2004. Economists see benefits to Bush's plan. Los Angeles Times, 8 January, A14.

Waldinger, Roger and Michael I. Lichter. 2003. How the Other Half Works: Immigration and Social Organization: Immigration and the Social Organization of Labor. Los Angeles: University of California Press.

Wallerstein, Immanuel. 1974. The Modern World System: Capitalist Agriculture and the Origin of the European World Economy in the Sixteenth Century. New York: Academic Press.

Wallerstein, Immanuel. 1979. The Capitalist World Economy. Cambridge, U.K.: Cambridge University Press.

Williams, Raymond. 1966. Communication. Harmondsworth: Penguin Books.

Wright, Richard and Mark Ellis. 2000. The ethnic and gender division of labor compared among immigrants to Los Angeles. International Journal of Urban and Regional Research 24(3), 683-700. 